\title{
北海道農村地域における町村単位に見た集会研修及びスポーツ等の 複合施設利用者数推定のための計算図と推定結果の検証について
}

公的複合施設の需要予測に関する研究 その 3

ON THE NOMOGRAMS AND THE PROOF OF RESULTS OF ESTIMATING THE NUMBER OF USERS OF MULTIPLE-USE FACILITIES FOR GATHERING, STUDYING AND SPORTS IN RURAL AREAS IN HOKKAIDO FROM THE VIEWPOINT OF THE TOWN AND VILLAGE UNIT

The estimate of demand for Public Multiple-Use facilities Part 3

\author{
坂原弘也* \\ Koya SAKAHARA
}

\begin{abstract}
In this paper, on the basis of our former indexes, we make the nomograms for estimating the number of users. Using these nomogrames, we estimate the number of users of multiple-use facilities for gathering, studying and sports in 106 towns and villages in Japan. And then, we calculate the relative error (actual users / estimated number of users) and show that we can apply this estimating method to the actual planning if we will allow about $0.75 \sim 1.25$ for the calculating error.
\end{abstract}

Keywords : the nomograms, the proof of the result, rural areas, multiple-use facilities 計算図表, 結果の検証, 農村地域, 複合施設

\section{1.はじめに}

前 2 報の,「その 1」で推定の枠組みを決定し,「その 2」

で,これに必要な諸指標を揭載し，3町村への適用事例 について, 考察した。

本研究の目的は，前報の各指標を整理して，簡便に利 用者数を推定可能な計算図を提示し，推定結果を検証す ることである。

本推定による利用者数推定の手順は，複雑である。一 方, 実際の計画に適用しようとするとき, 諸指標の組合 せ・計算手法が簡便で, 分かりやすいことが必要条件と 考える。このような観点から，6つ（1趣味活動による 利用・(2)集会研修活動による利用・(3)スポーツ活動によ る利用 (スポーツ活動は激しいスポーツとスポーツー般 を 1 つの図にまとめた) - (4)図書閲覧による利用・(5)冠 婚葬祭による利用・(6)体育館等の一般開放による利用) の大まかな活動区分ごとに計算図部文を作成し，具体的 計画への適用を促進しようとするものである。なお，表 -1 に，一連の計算図に必要な諸指標の回帰式・相関係 数（参考文献 8 図一2 9 参照）を一覧表にして示す。
この計算図を用いて全国 106 か町村に適用し，実数值 との対応を試み，この推定方法の妥当性を検討する。本 推定は，北海道における町村単位の諸デー夕を用いてそ のすう勢を延長するかたちで推定を組み立てた。した がって，本来ならば，北海道における「その2」の諸指 標作成に無関係の町村に適用し，推定方法の妥当性を検 討すべきである。しかし，施設の機能・規模・年間利用 者数等推定に必要なデータ入手可能な町村が 13 か町村 しかなかったので, 推定値と実数值の対応を北海道以外 の府県にも拡大して適応し，結果の検討をする。なお， 府県の場合, 伝統・営農形態・居住形態等が北海道とは 異なり，施設の使われ方にも違いがあると考えられる。 しかし，本研究では，行政区分としての町村全体を利用 圈域とする施設とその利用者数を問題にしている。した がうて，利用者数の各施設への配分等，個別の施設計画 に言及しない限り（町村全体の推定による利用者数と実 数值によるいくつかの施設利用者数の合計の対応に限 定)，大きな問題にならないと考える。

本研究は，町村単位に集会研修及びスポーツ施設利用 
者数を推定している。この理由を参考文献 5) でも指摘 したが，施設計画と利用者数推定の観点から，その理由 を以下に箇条書きにして示す。

(1) 人口が都市部と比較して圧倒的に少ない農村（過疎 地域）では，施設の側から見ると，1 施設で十分な利用 （年 100 回が標準等と言われている）を期待できない機 能が多い。この場合，各施設の機能分担もしくは施設の 複合的利用がなされる。したがって，町村全体として， 集会・研修・スポーツ活動を考える方が，より合理的で あると考える。

(2) 新たに施設が計画された場合, 過疎地域では, 施設 の増加による利用者の誘発を考慮しても類似施設の利用 者数減少につながる恐れがある。したがって，公共施設 として計画されることを考えると，耐用年数のある既存 施設を含めた町村全体のバランスを考慮する必要があ る。

(3) 今後, 過疎と高粭化が進行する農村地域にあっては, 学校教育施設を含めた公的諸施設の複合化計画を積極的 に進め,行政的コストの削減を計る必要がある。したがっ て, 町村単位の利用者数推定は, 複合化計画の基礎的資 料として重要な位置を占めると考える。

\section{2. 計算図について}

利用者数推定のために作成した計算図は，6種類 [図 -1 ・趣味的活動による利用，図一 2 ・図書閲覧による利 用, 図一 3 - 集会研修活動による利用, 図一 4 - 冠婚葬祭
による利用, 図一5・スポーツ活動による利用（スポー ツ一般・激しいスポーツ), 図一6・体育館等の一般開放 による利用]，である。これらの図は，表一1に示す回 帰式を図化したものである。図一1〜 4 が趣味及び集会 研修活動による利用, 図一 $5 \cdot 7$ はスポーツ活動の場合 である。一方，団体による利用は図一 $1 \cdot 3 \cdot 5$, 団体に よらない利用は図一 $2 \cdot 4 \cdot 6$ である。

本研究で対象とする農村地域における集会研修及びス ポーツ施設（参考文献 4 [p. 84「5-2 町村単位で考えた 複合的利用と施設充実の程度」] 参照のこと）は，名称・ 外見がスポーツ施設であっても，スポーツ活動が主体で はあるが，冠婚葬祭・大規模集会活動への利用割合も高 い。一方, 集会研修施設であっても, 卓球・ジャズダン ス等のスポーツ活動が, 多目的ホール等で行われ, 冠婚 葬祭の利用も多数みられる。また，これらの組み合わせ がどこの町村でも同一ということはなく，施設の施設状 況等によって, 様々に変化する。したがって, 以下の計 算図の使用に当たり, 該当町村の実状を調査し, 使用す る計算図の選択が必要となる。

団体による利用者数の計算手順（図一 1 ・図-3・図5)は, 次のとおりである。

この計算図は $\mathrm{A} \sim \mathrm{D}$ の部分からなり, 各座標軸に I IVの番号を付け， [I 軸：加入率] - [II 軸：加入者数 ] [III軸：参加者数] - [IV 軸 : 年間利用者数 (左側) $「 1$ 人 当たり面積時間（施設充実の程度 : 右側)」] とする。な お，計算を始める前に，「1 人当たり面積時間」・「従業

表一1 利用者数推定に使用した回帰式一覧表

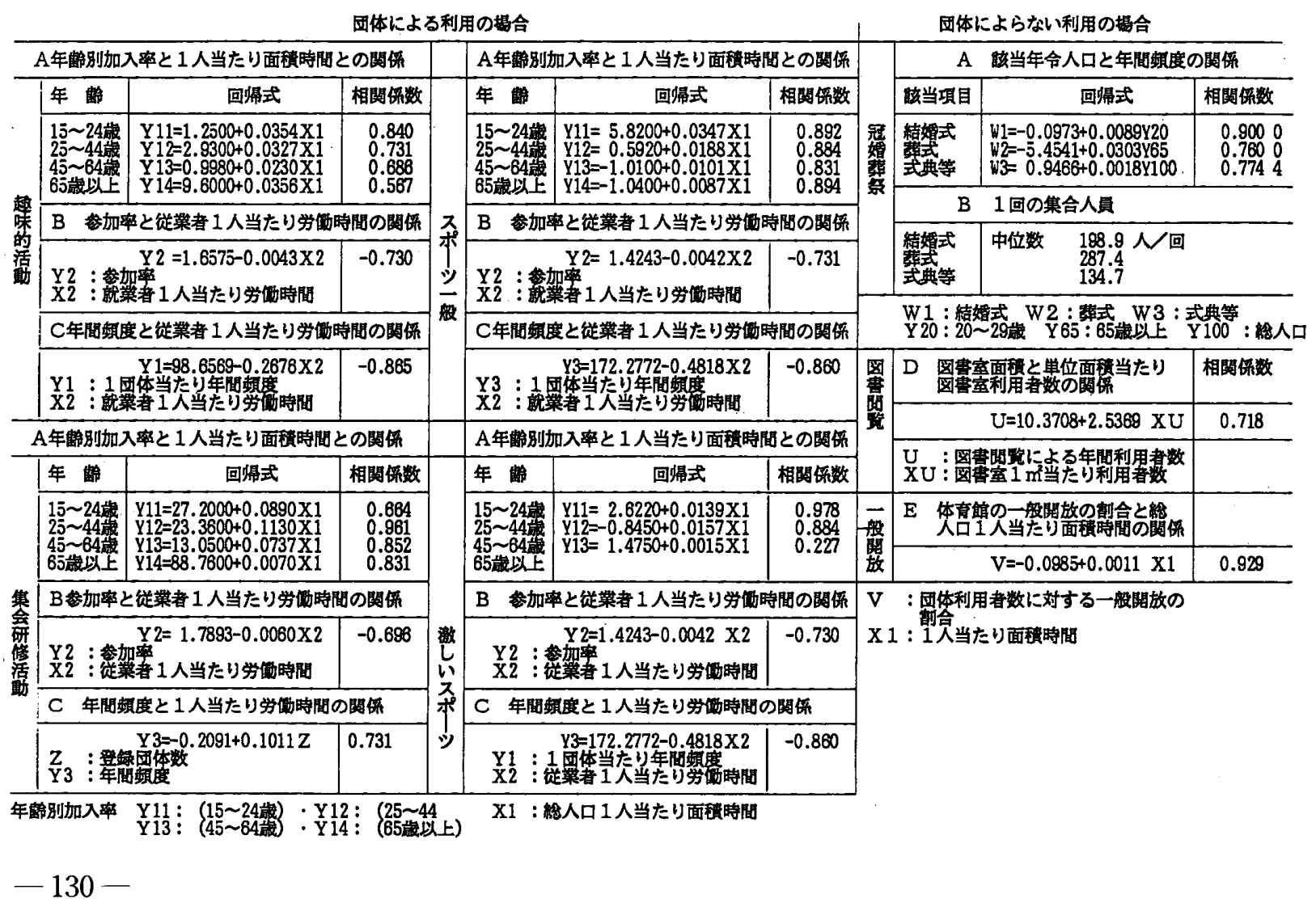


者 1 人当たり労働時間」を 計算する必要がある。なお， これらの計算方法は前報 [参考文献 8)：その 2 . p.119 付表一1・2] にそ の計算方法を説明してい る。

A I 軸右側の「1人当た り面積時間」とI軸の「年 秢別加入率」の関係から, 該当年歯の「加入率」を算 出する。図中の曲線は, 前 報 [参考文献 8)：その 2 ・ 図一2] の回帰式を対数で 表現した結果である。なお， 「年齢別加入率」は,「加入 率」の最大值を考慮して, $80 \%$ を限とするが, 集 会研修活動の 65 歳以上は, 老人クラブへの加入を加味 して $95 \%$ とする。

B 年㱓別団体加入者数を 算出する。加入者数は, 該 当年㱓人口に年榆別加入率 を掛けて算出する。斜線 は，I 軸の加入率と年粭別 人口との対応線である。

C 会合 1 回当たり参加者 数（[団体加入者数] $\times$ [参 加率]）を計算する。図中 の直線は, 町村単位の「従 業者 1 人当たり労働時間」 之「参加率」の関係 [参考 文献 8) - 図-3] 加ら, II 軸の加入者に「参加率」を 掛けて, III軸の参加者数を 算出する対応線である。

$\mathrm{D}$ 年齿別年間利用者数を 読み取る。年間利用者数は 1 回の会合への参加者数に 「年間頻度」を掛けて算出 する。この直線も [C] と 同様，「従業者 1 人当たり 労働時間」之「年間頻度」 の関係 [参考文献 8)：そ の $2 \cdot$ 図-4] から作成し た。なお, 集会研修活動は, 登録団体数と年間頻度の関

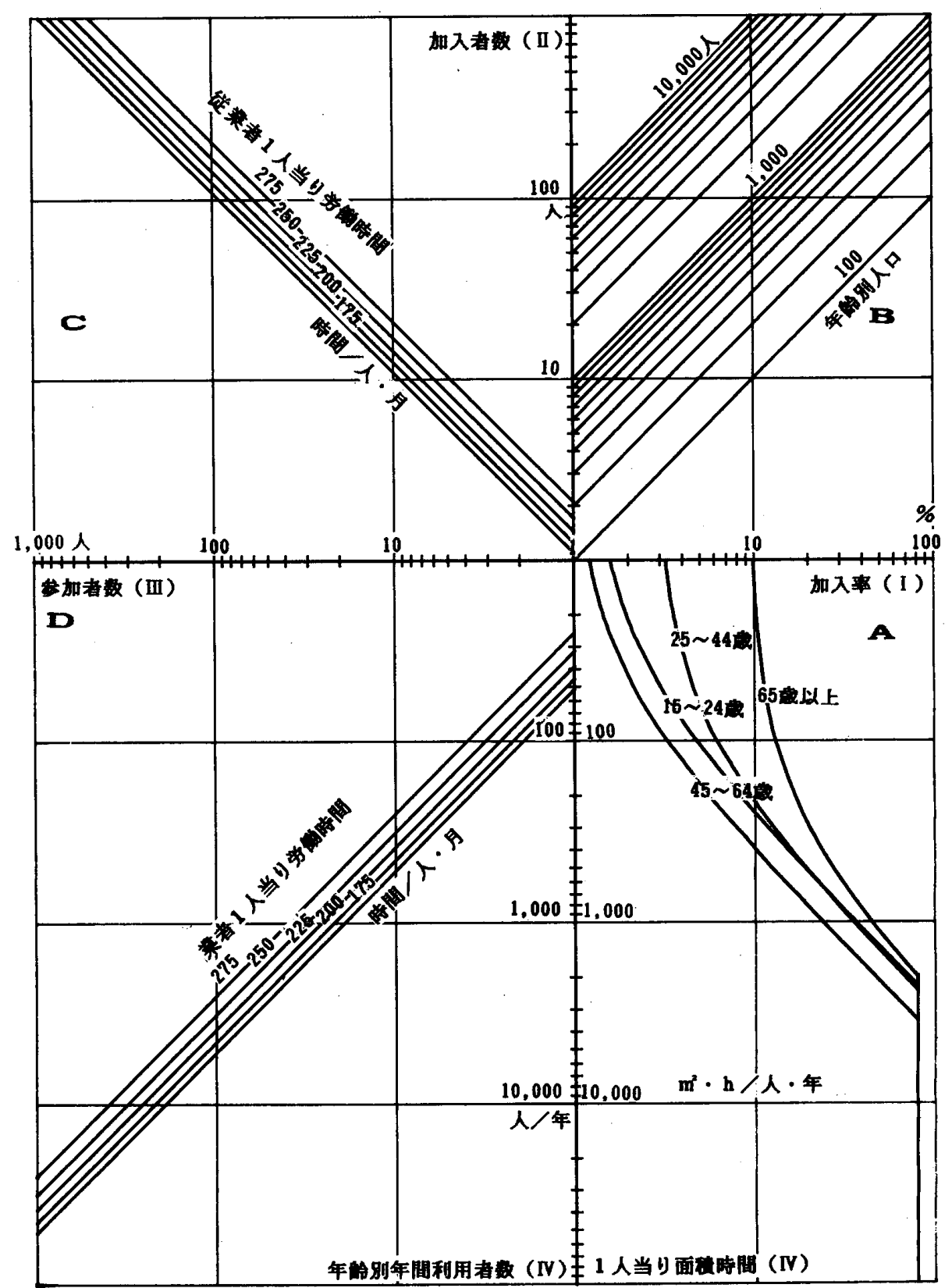

図一1趣味活動による利用者数計算図

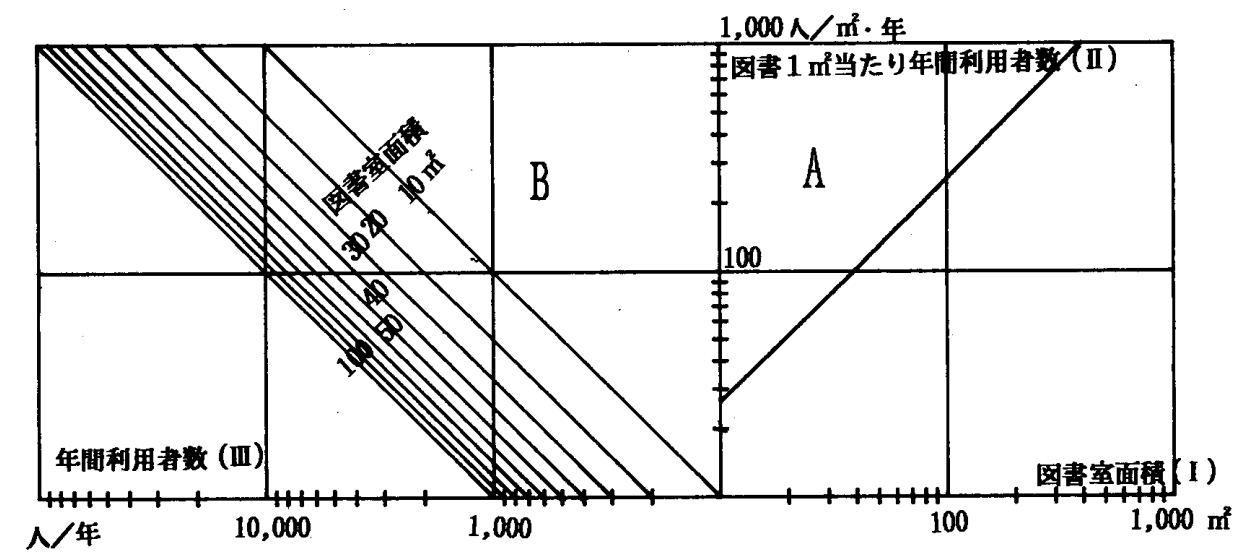

図一2 図書室利用者数計算図 
係加作成 [参考文献 8)

:その 2 : 図一5]した。 以上の手順を年跲別に施 し，これらを合計したもの が，該当年度の団体による 利用者数である。

次に，団体によらない利 用者数の計算図について, 説明する。

図書閲覧による利用者数 は, [A：図書室面積 $] \times[B$ : 図書室. $1 \mathrm{~m}^{2}$ 当たり年間 利用者]で計算する。この 計算図を図一 2 に示す。I 軸に図書室面積（計画施設 と既存の図書室面積の合 計）をとり，【軸の室面積 $1 \mathrm{~m}^{2}$ 当たり利用者数を読 み取る。次に，該当町村の 図書室合計の直線を垂直に 下ろした第血軸の值が，求 める年間利用者数である。

冠婚葬祭は, [A：年間 頻度 $] \times[\mathrm{B}: 1$ 回の集合人 員]で計算する。この計算 図を図一4に示す。例えば, 結婚式は次のようになる。 該当年齢人口と頻度の関係 から，I軸に 20 代人口を とり，II 軸の年間頻度を読 みとる。 $\mathrm{B}$ は, II 軸の頻度 に 1 回の集合人員を掛け て，四軸の年間利用者数を 読み取れるように引いたも のである。また, 葬式・式 典他も I 軸の人口が， 65 歳以上・総人口である点を 除いて同じである。

体育館の一般開放による 利用者数は， [A：団体利 用者数に対する一般開放の 割合 $] \times[B ：$ 団体による利 用者数]で計算する。この 計算図を図一 6 に示す。な お，I軸の「 1 当たり面積 時間」はスポーツ施設につ いて計算し，団体によるス ポーツ施設利用者数は, 図

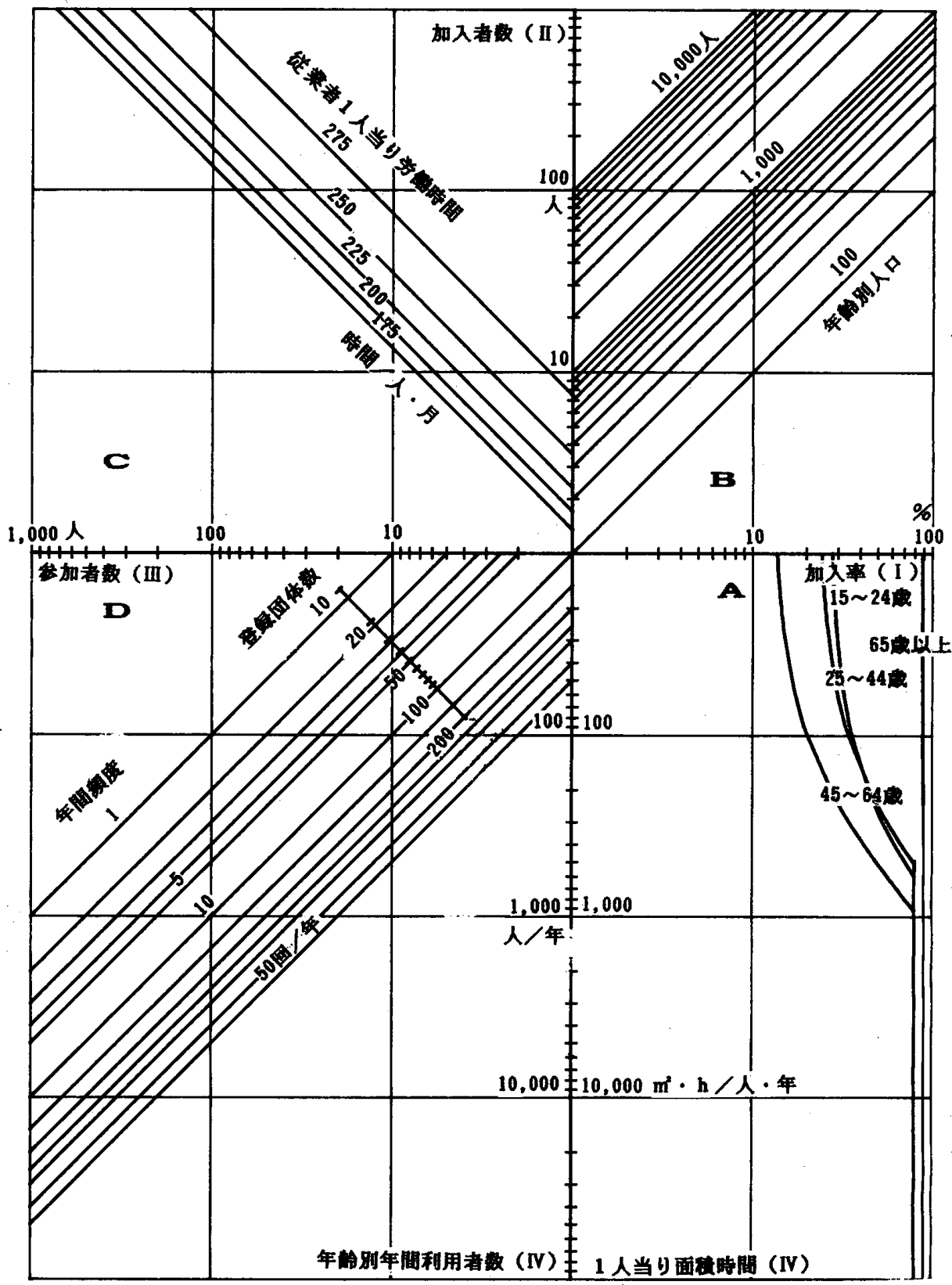

図一3 集会研修活動による利用者数計算図

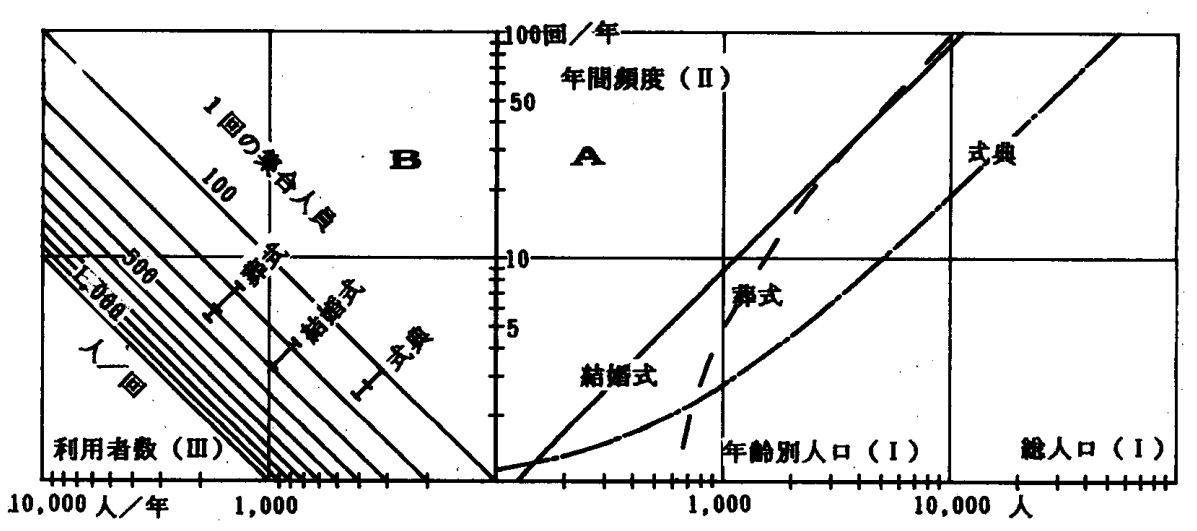

図一4冠婚葬祭による利用者数計算図 
一5で計算されるスポーツ 施設利用者数の合計に最も 近い直線を用いる。

\section{3. 結果の検討}

推定結果の検討に必要な 実数值は，参考文献 6）か ら, 農村環境改善センター と類似する機能を持つ施設 の面積 (有効面積) - 年間 利用者数の明らかな町村の 施設とした。一般に 1 町村 に複数の集会研修施設が存 在し, スポーツ活動に学校 開放による小中学校の体育 館の利用を合わせる町村も 多い。「1 人当たり面積時 間（施設充実の程度）」は， 調查年度 (参考文献 6) の 報告書が作成された年度） に最も近い国調值による総 人口・有効面積注2) - 年間 開放時間主3) 用いて算出 し，「従業者 1 人当たり労 働時間」は，参考文献 4) の付図と同様に計算した。 なお，年龄別人口は，調查 年度に最も近い国調値とし た。集会研修施設とスポー ツ施設の区分は，施設名称 によった。また，各施設に おける活動内容は, 原則と して，集会研修施設では趣 味・集会研修活動・冠婚葬 祭・図書閲覧，スポーツ施 設ではスポーツ活動（ス ポーツ一般・激しいスポー ッ)・一般開放による利用， として計算した。しかし, 「集会研修施設で一部軽ス ポーツが行われている」等 の事情が参考文献 6）に記 述されている町村は，この 記述に従った。

表一 $2 \cdot 3$ は，計算図に よる全国 106 か市町村の推 定結果・実数値及び誤差率 (推計値 $\div$ 実数値) の一覧

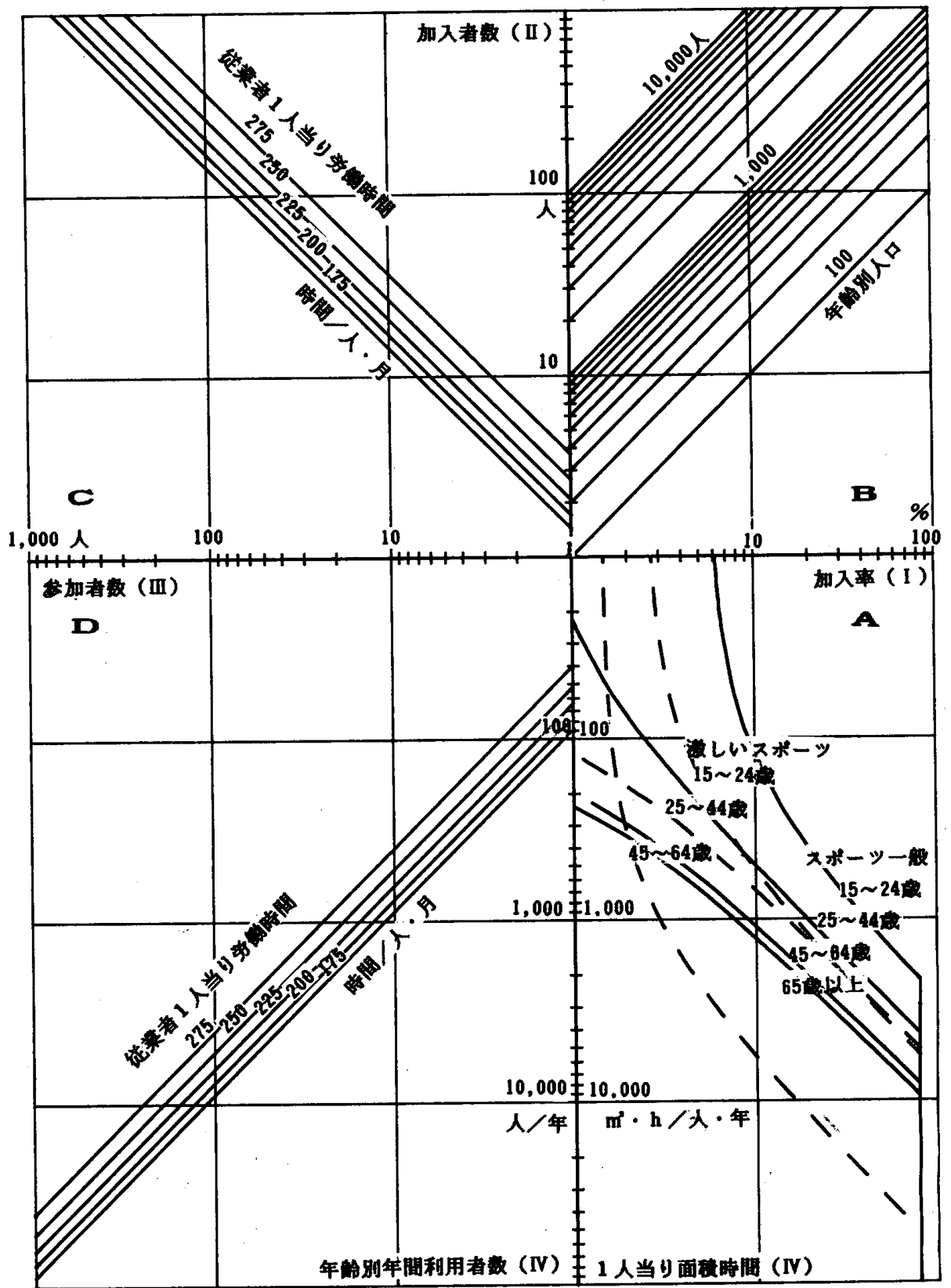

図一5 スポーツ活動による利用者数計算図

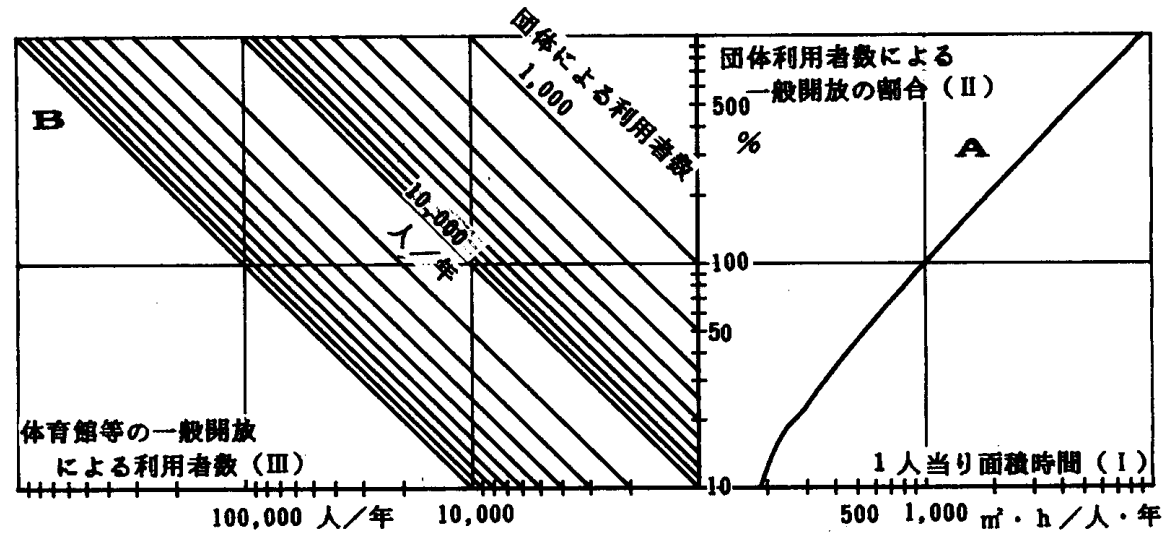

図一6 体育館の一般開放による利用者数計算図 
表一2 推計結果一覧表一集会研修施設一

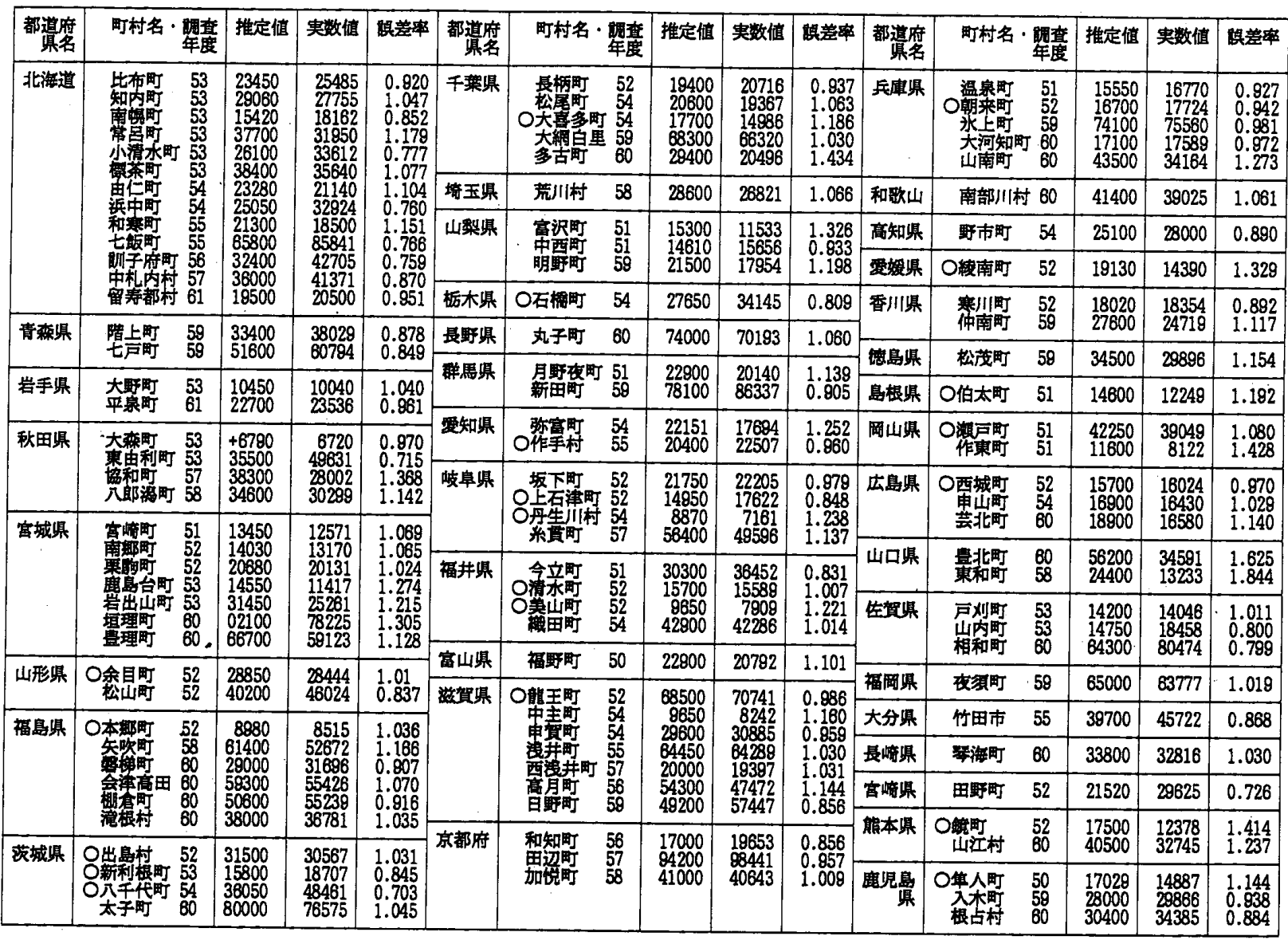

表一3 推計結果一覧表一スポーツ施設一

\begin{tabular}{|c|c|c|c|c|c|c|c|c|c|c|c|c|c|c|}
\hline $\begin{array}{l}\text { 都道腐 } \\
\text { 尊 } \\
\end{array}$ & 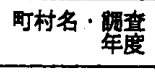 & 推定值 & 实数值 & 踶荎率 & $\begin{array}{l}\text { 都道䫊 } \\
\end{array}$ & 町村名·解﨎 & 推定值 & 实数值 & 镇差玮 & 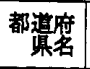 & 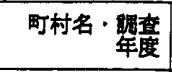 & 推定值 & 実数值 & 期䖭率 \\
\hline \multirow[t]{4}{*}{ 北海道 } & \multirow{4}{*}{ 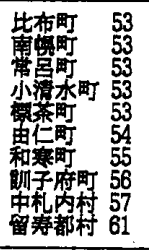 } & \multirow{4}{*}{$\begin{array}{r}15620 \\
11300 \\
26300 \\
1050 \\
7720 \\
22300 \\
15700 \\
1800 \\
24100 \\
5200 \\
\end{array}$} & \multirow{4}{*}{$\begin{array}{r}20000 \\
11325 \\
25795 \\
9010 \\
8550 \\
21912 \\
12481 \\
19505 \\
23739 \\
5150 \\
\end{array}$} & \multirow{4}{*}{$\begin{array}{l}0.781 \\
1.094 \\
1.017 \\
1.115 \\
0.803 \\
1.017 \\
1.258 \\
0.923 \\
1.015 \\
1.010\end{array}$} & 宫城県 & 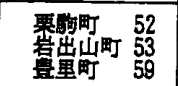 & $\begin{array}{l}16848 \\
36724 \\
36744\end{array}$ & $\begin{array}{l}19633 \\
37914 \\
35210\end{array}$ & $\begin{array}{l}0.850 \\
0.969 \\
1.044\end{array}$ & 㤎賀県 & 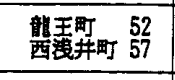 & $\begin{array}{r}14650 \\
4600 \\
\end{array}$ & $\begin{array}{r}13698 \\
7178 \\
\end{array}$ & $\begin{array}{l}1.069 \\
0.641\end{array}$ \\
\hline & & & & & 山形県 & 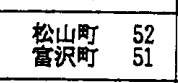 & $\begin{array}{r}6870 \\
20600 \\
\end{array}$ & $\begin{array}{r}5000 \\
27870 \\
\end{array}$ & $\begin{array}{l}1.337 \\
0.736 \\
\end{array}$ & \multirow[t]{2}{*}{ 兵庫県 } & \multirow{2}{*}{ 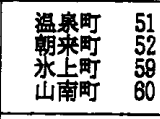 } & \multirow{2}{*}{$\begin{array}{r}2795 \\
18350 \\
39700 \\
26100 \\
\end{array}$} & \multirow{2}{*}{$\begin{array}{r}2940 \\
18770 \\
35135 \\
21454 \\
\end{array}$} & \multirow{2}{*}{$\begin{array}{l}0.951 \\
0.978 \\
1.130 \\
1.217 \\
\end{array}$} \\
\hline & & & & & 福井県 & ○今庄町 51 & 8500 & 7210 & 1.179 & & & & & \\
\hline & & & & & 富山惧 & O福野町 50 & 6180 & 5820 & 0.840 & 香川県 & ○寒川町 52 & 14650 & 17910 & 0.818 \\
\hline 青㷊県 & 陵上町 58 & 31700 & 30613 & 1.036 & 岥阜県 & ○奴下町 52 & 10950 & 10625 & 1.028 & \multirow[b]{2}{*}{ 程岡県 } & \multirow{2}{*}{ 夜榊町 60} & 30800 & 22253 & 1.384 \\
\hline 岩手県 & 平家町 60 & 12400 & 9715 & 1.276 & 長野県 & 丸子町 60 & 87500 & 118300 & 0.740 & & & 36000 & 28074 & 1.282 \\
\hline
\end{tabular}

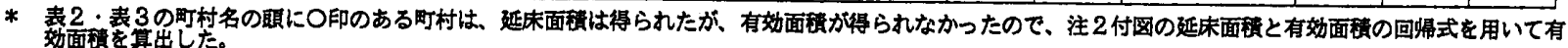

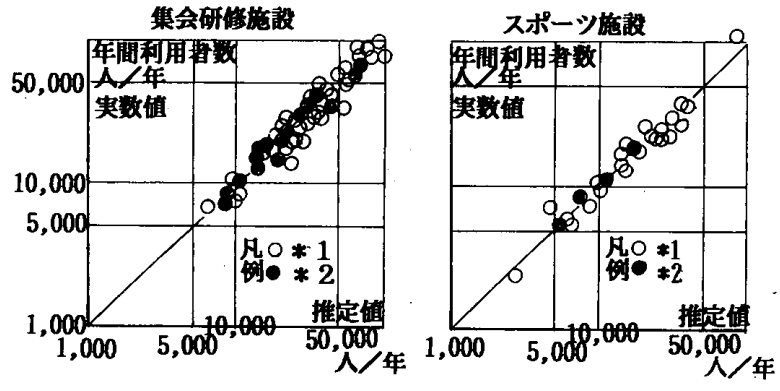

図一7 推定値と実数値の対応

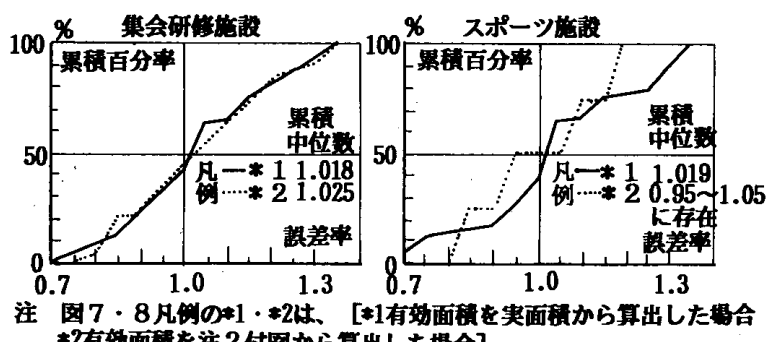

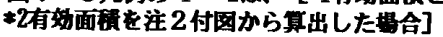

图一8 誤差率の累積百分率
表である。なお，個々の施設の有効面積が得られず，延 べ床面積之有効面積の回㷌式部付困加ら算出した町村は, 町村名の頭に丸印をつけた。図一7は, 実数值之推計値
の対応である。両者は 45 度の線に沿って分布し，特に 大きい偏りは見られない。また，有効面積が実数の場合 と推定による場合の差も問題にならない。 
表一4 誤差率の度数分布一覧表

\begin{tabular}{|c|c|c|c|c|c|c|c|c|c|c|c|c|c|c|c|c|c|}
\hline & & 稹差 & $\begin{array}{l}0.70 \\
\text { 以下 }\end{array}$ & $\begin{array}{l}0.70 \\
0.75\end{array}$ & $\begin{array}{c}0.75 \\
1.80 \\
0.80\end{array}$ & $\begin{array}{l}0.80 \\
0.85 \\
0.8\end{array}$ & $\begin{array}{l}0.85 \\
0.80\end{array}$ & $\begin{array}{l}0.80 \\
0.95 \\
\end{array}$ & $\begin{array}{l}0.95 \\
1.00 \\
1.00\end{array}$ & $\begin{array}{l}1.00 \\
1.05\end{array}$ & \begin{tabular}{l|}
1.05 \\
1.10 \\
\end{tabular} & $\begin{array}{l}1.10 \\
1.15 \\
\end{array}$ & $\begin{array}{l}1.15 \\
1.20 \\
\end{array}$ & $\begin{array}{l}1.20 \\
1.25 \\
\end{array}$ & $\begin{array}{l}1.25 \\
1.30 \\
\end{array}$ & $\begin{array}{l}1.30 \\
\text { 以上 }\end{array}$ & 合賥 \\
\hline \multirow{2}{*}{ 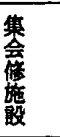 } & 1 有奻面䅡が実数で斯の椙合 & 百分率 (\%) & 0.0 & $\begin{array}{r}3 \\
3.4 \\
\end{array}$ & $\begin{array}{r}4 \\
4.6 \\
\end{array}$ & 4.6 & $\begin{array}{r}9 \\
10.3 \\
\end{array}$ & 8.7 & \begin{tabular}{r|}
9 \\
10.3 \\
\end{tabular} & $\begin{array}{r}21 \\
24.1 \\
\end{array}$ & $1 . \frac{1}{1}$ & $\begin{array}{r}9 \\
10.3 \\
\end{array}$ & $\begin{array}{r}5 \\
5.7 \\
\end{array}$ & $\begin{array}{r}5 \\
5.7 \\
\end{array}$ & 2.2 & $\begin{array}{r}8 \\
9.1 \\
\end{array}$ & $\begin{array}{r}87 \\
100.0 \\
\end{array}$ \\
\hline & 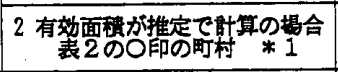 & 百分率 (嚄) & 0.0 & 0.0 & 5.3 & $\begin{array}{r}3 \\
15.7 \\
\end{array}$ & 0.0 & 10.5 & 10.5 & $\begin{array}{r}3 \\
15.7 \\
\end{array}$ & 10.2 & $5 . \frac{1}{2}$ & $\begin{array}{r}2 \\
10.2 \\
\end{array}$ & 5.2 & $5 . \frac{1}{2}$ & $5 . \frac{1}{2}$ & $\begin{array}{r}19 \\
100.0 \\
\end{array}$ \\
\hline \multirow{2}{*}{ 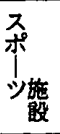 } & 1 有効面樌が央数で䀦拏の坦合 & 百分率 $(\%)$ & $3 . \frac{1}{8}$ & $7.6^{2}$ & $3 . \frac{1}{8}$ & 0.0 & $3 . \frac{1}{1}$ & 7.2 & $\begin{array}{r}3 \\
11.5 \\
\end{array}$ & 30.7 & $\begin{array}{r}0 \\
0.0\end{array}$ & 7.2 & 0.0 & $3 . \frac{1}{8}$ & $\begin{array}{r}3 \\
11.5 \\
\end{array}$ & 7.2 & 100.0 \\
\hline & 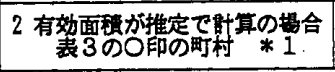 & 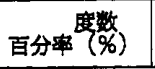 & 0.0 & 0.0 & 0.0 & 25.0 & 0.0 & 25.0 & 0.0 & $\begin{array}{r}0 \\
0.0 \\
\end{array}$ & 25.0 & 0.0 & 25.0 & 0.0 & 0.0 & 0.0 & $100.0^{4}$ \\
\hline
\end{tabular}

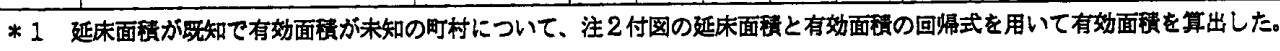

表一4 は，誤差率の度数分布である。誤差率が 0.75 1.25 の範囲内に集会研修施設は有効面積実数の場合, 全体の $85 \%$, 有効面積を推定の場合, $90 \%$ が含まれる。 スポーツ施設は有効面積実数の場合，全体の $70 \%$, 有 効面積推定の場合はすべて含まれる。

図一8 は, 表一 4 の誤差率の度数分布を累積百分率で 表したものである。集会研修とスポーツは，中位数・累 積百分率の傾向もよく似ている。

筆者らの実態調查によれば, 施設利用者の経年的変化 は増減を繰り返す。その割合は利用者数の少ない町村程 大きく，前年度の 0.7 - 0.5 倍及び $1.3 \sim 1.5$ 倍になる場 合もある。この点と推計值と実数值との対応及び誤差率 の分布 (単一年度の誤差率が $0.75 \sim 1.25$ の範囲内に大 多数が含まれる）等から，この方法による施設利用者数 の推定結果は, 誤差率を 0.75〜1.25 程度見込むならば, 規模計画・利用予測の基礎資料として有効であると考え る。

\section{4. まとめ}

本論文は，利用者数推定のための計算図を提示し，そ の有効性を示した。以下に，これらのまとめと今後の課 題を箇条書きにして示す。

(1) 実態調査等により経年的傾向の一致を確認するなら ば，この方法による推定結果を具体的計画 (単一年度で 誤差率を $0.75 \sim 1.25$ 程度見込んで）に適用可能である。 (2) 本推定で活動内容が変化する要素は，年橉別人口だ けである。新たな団体・種目の出現・消隇に年齢別人口 は大きく関与するであろうが，他にも原因があろう。今 後，新規施設建設による町村全体の利用者増の中味を実 態調査から分析し, サークル等の出現・消滅のメカニズ ムを解明する必要があろう。

(3) 府県の町村は, 一般に北海道に比べて一戸当たり耕 地面積も少なく，農業における兼業の度合いも高い。し たがって, 労働時間との関係が深い参加率・年間頻度等 は, 地域別にデー夕を用意する必要も考えられる。

(4)一般に, 同一町村に類似する機能を有する施設が複 数存在する。施設側面積時間 (参考文献 5 [p. $64: 3-1$ 「利 用率」と「施設充奉の程度」]参照) に比例すると仮定
して, 利用者数を配分するのもやりかたの 1 つであるが， さらに, 各施設の機能・平面構成等を考慮した配分方法 も必要亡なろう。

\section{謝 辞}

本研究を進めるに当たり, 農村環境改善センター基本 計画作成時の調査にご協力いただいた該当町村担当職員 の方々・北海道職員ならびに全国農業改善協会調䍒役の 皆様に，心からお礼を申し上げるとともに，深く感謝い たします。また，北海道工業大学菊地弘明教授には，実 態調査に便宜をはかっていただくとともに, 研究遂行上 様々のご指導を賜り，深く感謝いたします。

注

1）(1)（6)の活動ごとの利用者数の計算方法は, 参考文献 7) [p.147：5.1 利用者数の計算方法] で示したが，ここに その概略を載せる。なお，(1)～(6)は，本文の「(1)趣味活 動による利用」等の番号と一致する。

（1）団体で利用する場合の利用者数：(1)・(2)・(3) $[$ 年秢別人口 $] \times[$ 年路別加入率 $] \times[$ 参加率 $] \times[$ 年間 頻度]

（2）団体によらないで利用する場合の利用者数

(4) 図書閲覽による利用

[図書室面積 $] \times$ [図書室単位面積当たり利用者 数]

(5) 冠婚葬祭による利用 [年間頻度 $] \times[1$ 回当たり集合人員 $]$

(6) 体育館等の一般開放による利用 [団体利用者に対する一般開放利用者の割合］ $\times$ [団体利用者（スポーツ活動による］

2）有効面積は，該当施設の使用目的に使われる諸室の面積 合計で，本研究で問題としている集会研修及びスポーツ 等の複合施設の場合は, 会議室・多目的ホール・調理奏 習室・アリ一ナ等の諸室で, 延べ休面積から事務管理部 門・廊下等の室内交通部門等を差し引いた面積である。 付図に参考文献 6) のうち, 延べ休面積・各室面積の記 載のあった 88 施設について, 延べ床面積と有効面積の関 係を示す。結果の検証に当たり，府県の町村で施設の延 ベ床面積と年間利用者数の記述しかない施設の有効面積 は,この回帰式を用いて推定した。

3）一般的な施設の場合, 特に記述がないかぎり, 1 日の開 館時間が 12 時間・年間開館日数を 300 日 (日曜・祝祭日 を除く)として，計算した。しかし，学校開放による小 


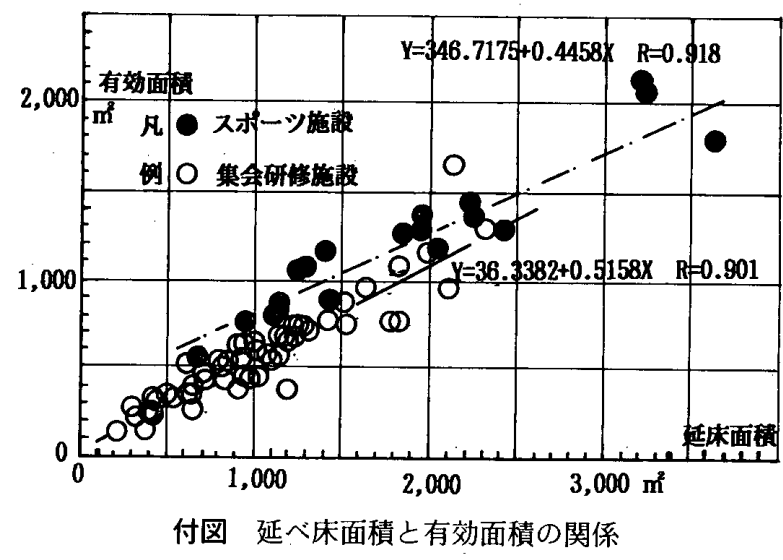

中学校等の体育館の利用について, 参考文献 6) では, 体育館の面積と年間利用者数の記述にとよ゙まっていた。 したがって, 府県の場合も北海道における実態調查時点 のヒァリング等を基に，大まかな仮定であるが，1日 3 時間（夜間）利用・年間 150 日（日曜・祝祭日・春夏冬 休みを考虑しで)として，計算した。

\section{参考文献}

1）坂原弘也, 菊地弘明：農村地域における年齢別人口の予 測について, 農村計画学会誌, Vol. 1, No.4, pp. 39 48, 1983.4
2）坂原弘也：北海道農村地域の社会教育施設利用者の特性, 農村計画学会誌, Vol. 5, No.2, pp.8 17, 1986.9

3）坂原弘也, 㐘地弘明：農村地域の社会教育施設の規模決 定について，地域施設研究 I 第 1 回地域施設計画シン ポジウム, pp. 141 150, 1983.4

4）坂原弘也：北海道町村部における集会研修および体育等 の複合施設の利用者特性について, 日本建築学会計画系 論文報告集，第 397 号, pp. 80 88, 1989.3

5）坂原弘也：北海道町村部における集会研修および体育等 の複合施設利用率と利用者要望について, 日本建築学会 計画系論文報告集，第 406 号，pp.63 71，1989. 12

6）農村環境改善センター基本計画調查診断報告書, 全国農 業構造改善協会, 1973 1986

7）坂原弘也：北海道農村地域における町村単位に見た集会 研修及びスポーツ等の複合施設利用者数の推定方法につ いて一公的複合施設の需要予測に関する研究一その 1 , 日本建築学会計画系論文報告集, 第 443 号, pp. 143 149, 1993.1

8）坂原弘也：北海道農村地域における町村単位に見た集会 研修及びスポーツ等の複合施設利用者数の推定に必要な 諸指標と具体例への適用について一公的複合施設の需要 予測に関する研究一その 2; 日本建築学会計画系論文報 告集, 第 448 号, pp. 111 119, 1993.6

(1993 年 4 月 28 日原稿受理, 1993 年 10 月 18 日採用決定) 